\title{
Middle and Late Holocene Vegetation history of the Murcia region from a new high-resolution pollen sequence from the Mar Menor Lagoon
}

\author{
Azuara Julien ${ }^{1}$, Lebreton Vincent ${ }^{1}$, Dezileau Laurent ${ }^{2}$, PérezRuzafa Angel ${ }^{3}$, Combourieu-Nebout Nathalie ${ }^{1}$
}

1. HNHP, Muséum National d'Histoire Naturelle, UMR CNRS 7194, 75013 Paris, France

2. M2C, Université de Caen, UMR 6143, 14000 Caen, France

3. Departamento de Ecología e Hidrología, Facultad de Biología, Regional Campus of International Excellence "Mare Nostrum," University of Murcia, 30100 Murcia, Spain

\section{Keywords}

Palynology, coastal lagoon, vegetation changes, human impact, resilience, ecological succession, Argar period, Classical Antiquity, Historic period, lead concentration, mining activities

\begin{abstract}
South-Eastern Spain is a particularly suitable area for studying the impact of human societies on their environment. We present a new high resolution and continuous pollen sequence from the coastal lagoon of Mar Menor in the Murcia region. This new sequence covers the last 6500 years, from the end of the Neolithic to the present period, with a robust chronological framework (17 radiocarbon dates). The history of vegetation obtained from pollen data is studied in parallel with a proxy of mining activity in the watershed of the same lagoon to disentangle the influence of human activities and climate change on the vegetation of this part of the Iberian Peninsula. While the influence of past climate variability on the vegetation in the Murcia region remains difficult to perceive, the data show a very clear concomitance between changes in the archaeological record and changes within plant communities.
\end{abstract}

- Important deforestation and changes in herbaceous communitites during the Argar period (early Bronze Age)

- Changes in the thermo-Mediterranean shrub communities in relation with the very important pastoral practices

- Major vegetation changes linked with mining and agricultural activities during the Roman period

- Impact on the regional vegetation of agricultural practices evolution between the $18^{\text {th }}$ and the $19^{\text {th }}$ Centuries.

The results obtained provide valuable indications for assessing the resilience of thermo-Mediterranean coastal plant communities to anthropogenic environmental changes.

\section{Introduction}

The Mediterranean area is one of the 34 biodiversity hotspots listed by Conservation International (Mittermeier 2011), while being a densely populated area for several thousand years. It is therefore a key area for studying past interactions between humans, their environments and climate changes. The Mediterranean is currently the scene of a major environmental crisis. Since the middle of the 20th Century, the demographic explosion, increasing urbanization, the rise of mass tourism, the development of intensive agriculture and the ongoing global warming have made environmental protection in this part of the world a huge challenge (Thiébault and Moatti 2016). In this context, understanding how Mediterranean ecosystems react to anthropogenic disturbances appears to be a necessity for better understanding the issues at stake in the current crisis. Paleoenvironmental studies are therefore becoming particularly crucial to understand the role of human societies in ecological dynamics in the short, medium and long terms and to assess the resilience capacity of these threatened environments. 
42 South-eastern Spain is particularly suitable for studying the impact of human societies on ecosystems. Indeed, 43 this part of the Iberian Peninsula is rich in a long history of human occupation by societies that each had a 44 particular influence on their environment, particularly in the Bronze Age with the Argar culture, in the Roman 45 period, during the Muslim period and finally in the 19th and 20th Centuries with industrialization and the 46 development of intensive agriculture. Moreover, in this region, the environmental impact is exerted on a great 47 diversity of very contrasting plant communities, from the lower thermo-Mediterranean formations of sub48 tropical affinities along the coast, which are among the driest environments in Europe, to the deciduous oak 49 formations of Euro-Siberian affinities in the mountain ranges further inland.

50 The study of vegetation history in south-eastern Spain has already been subject to numerous publications. 51 However, the search for sedimentary environments suitable for the conservation of paleoenvironmental markers 52 has led many studies to focus more on high-altitude sites (Carrión 2002b, Carrión et al. 2001, 2003, 2007, 53 Jiménez-Moreno and Anderson 2012, Ramos-Roman et al. 2016, 2018a, 2018b) while the history of coastal 54 environments is less documented (Carrión and Van Geel 1999, Pantaléon-Cano 2003, Burjachs 2012, Jiménez55 Moreno et al. 2015). In addition, most of these studies concern sites relatively far from the most densely 56 occupied areas in the past and therefore focus mainly on the influence of past climate change on ecosystems 57 (Carrión et al. 2001, Carrión 2002b, Pantaléon-Cano 2003, Carrión et al. 2003, Carrión et al. 2007, Jiménez58 Moreno and Anderson 2012, Jiménez-Moreno et al. 2015, Ramos-Roman et al. 2016, 2018a, 2018b). To date 59 much less work has been done specifically on the influence of human societies on vegetation (Carrión et al. 60 2007).

61 This study presents a new pollen sequence from the coastal lagoon of Mar Menor in the Murcia region. This new sequence covers continuously the last 6500 years from the end of the Neolithic to the present day, with a robust chronological framework. The history of vegetation obtained from pollen data is studied in parallel with a proxy of mining activity in the watershed of the same lagoon (Dezileau et al. in prep). The records of these two proxies are compared in detail with the regional historical and archaeological records as well as with paleoclimate data in order to disentangle the influence of human activities and climate change on the vegetation history of this part of the Iberian Peninsula. 
The studied sequence comes from the vast coastal lagoon of Mar Menor, one of the largest euhaline lagoons in Europe (Figure 1). It occupies about $135 \mathrm{~km}^{2}$ with an average depth of $3.6 \mathrm{~m}$ and is separated from the sea by a sandy barrier, "La Manga", $22 \mathrm{~km}$ long and between 30 and $500 \mathrm{~m}$ wide, pierced by five natural channels called "Golas" (Pérez-Ruzafa et al. 2005). This lagoon is located at the limit of a vast coastal plain, the "Campo de Cartagena", delimited to the south by coastal massifs including the mining massif of "Cartagena-La Unión" and to the northwest by two massifs belonging to the Baetic Cordillera, the "Sierra de Carrascoy" and the "Sierra Espuña" (Figure 1). The Mar Menor lagoon is fed by several temporary rivers (ramblas) which are dry for most of the year but can carry large quantities of sedimentary material during torrential rainfall episodes (GarcíaPintado et al. 2007). The main one, the Albujón rambla, drains a watershed of $441 \mathrm{~km}^{2}$, representing a third of the Campo de Cartagena. The MM2 core was collected far from the mouth of rivers, at about $8.5 \mathrm{~km}$ (Dezileau et al. 2016) and is therefore very insensitive to river inputs.

Figure 1 (color): a) Map of the main reliefs of the south-eastern Iberian Peninsula and distribution of the main pollen sequences of the region, b) Distribution map of the vegetation belts in the Murcia region.

The climate of the Murcia region is Mediterranean. It is characterized by significant seasonal contrasts with mild and humid winters and hot and dry summers. Rainfall is highest in autumn and lowest in summer. In the lowlands, the average annual rainfall is only between 250 and $330 \mathrm{~mm}$. The massifs of the Baetic Cordillera act as a shield against disturbances from the west. Annual rainfall can exceed $400 \mathrm{~mm}$ in the mountains and fall below $190 \mathrm{~mm}$ in the driest coastal areas while the average annual temperature is between 16 and $17^{\circ} \mathrm{C}$ (Carrión 2002a).

The Aleppo pine (Pinus halepensis), is one of the most abundant tree species in the Murcia region. It grows from sea level up to an altitude of $1500 \mathrm{~m}$. This species colonizes degraded shrub formations in which it can form dense and extensive populations. Further up in altitude, it often coexists in mixed formations with Quercus ilex subsp. ballota but can also be found in pure stands. Pinus halepensis represents $87 \%$ of the coverage of all wooded areas in the region (Sanchez-Gomez et al. 1998). Apart from this rather ubiquitous species, the vegetation in the Murcia region is organized into four altitudinal belts (Figure 1):

- The thermo-Mediterranean belt is characterized by average annual temperatures between 18 and $19{ }^{\circ} \mathrm{C}$, and an average temperature of the coldest month above $3^{\circ} \mathrm{C}$. In the Murcia region, it extends from the coast to an altitude of between 300 and $400 \mathrm{~m}$ asl, covering an area that represents almost half of the Murcia region. In the lower thermo-Mediterranean belt where winter frosts are very rare, a very open vegetation develops, characterized by the presence of thermophilous species of subtropical affinities such as Maytenus senegalensis subsp. europaea, Withania frutescens and Periploca angustifolia. At higher altitudes these species of subtropical affinities disappear or become occasional while shrub formations with Quercus coccifera, Pistacia lentiscus, Chamaerops humilis and Olea sylvestris are dominant. In the places of the thermo-Mediterranean belt where annual rainfall is between 350 and 600 $\mathrm{mm}$ these shrub formations are replaced by forests dominated by Quercus ilex subsp. ballota.

- The meso-Mediterranean belt also occupies a very large area of the Murcia region, where it extends up to an altitude of $1100 \mathrm{~m}$ asl. The average annual temperatures are between 13 and $18^{\circ} \mathrm{C}$ with average temperatures of the coldest month between 0 and $3^{\circ} \mathrm{C}$. When average annual rainfall is between 200$350 \mathrm{~mm}$, formations of Quercus coccifera and Rhamnus lycioides are found. They are replaced by forests of Quercus ilex subsp. ballota in areas with average annual rainfall between 350 and $600 \mathrm{~mm}$ and more mesophilic forests, still dominated by Quercus ilex subsp. ballota but with a significant presence of Quercus faginea when average annual rainfall exceeds $600 \mathrm{~mm}$.

- The supra-Mediterranean level has a limited extension. It occupies restricted areas in the highest regions, above $1100 \mathrm{~m}$ asl. It is found mainly in the Segura massif and to a lesser extent in the Espuña massif. Two formations notably stand out (Boucher 1988). Forests of Quercus ilex subsp. ballota accompanied by Berberis hispanica and Cytisus reverchonii are located in the driest areas, while forests 
of Quercus ilex subsp. ballota and Quercus faginea associated with Eurosiberian species such as Crataegus monogyna or Helleborus foetidus, are limited to the steepest parts of the massifs.

- The oro-mediterranean stage is found in the Sierra de Segura above $1600 \mathrm{~m}$ asl. It is essentially characterized by the presence of Pinus nigra subsp. salzmanni forests (Boucher 1988).

\section{Material and Method}

\section{Lithology and chronology of the core}

Only one core, MM2 (3.97 m long, Longitude $0.7502^{\circ} \mathrm{W} /$ Latitude $37.7233^{\circ} \mathrm{N}$ ), was collected from the Mar Menor lagoon. Sedimentation is largely dominated by fine clays and silts all along the core with eight coarsegrained layers of sand and shell fragments around 5, 40, 60, 150, 170, 210, 255, and $290 \mathrm{~cm}$, which mark storm deposits from the sandy barrier and are reported in red at the left side of the pollen diagram (Figure 3) (Dezileau et al. 2016). Those layers were not sampled for pollen analysis as they usually contain few pollen grains and display biased spectra (Azuara et al. 2015). The MM2 core age model is based on 17 radiocarbon AMS measurements performed on Cerastorderma glaucum shells (Dezileau et al. 2016). These ${ }^{14} \mathrm{C}$ dates, corrected for their reservoir effect (Sabatier et al. 2010, Dezileau et al. 2016), were calibrated with the Marine 13 calibration curve (Reimer et al. 2013). The MM2 core covers the last 6600 years. These dates were also supplemented by ${ }^{137} \mathrm{Cs}$ and ${ }^{210} \mathrm{~Pb}$ measurements in the most recent part of the sequence. A more detailed presentations of the MM2 core lithology and chronology is available in Dezileau et al. (2016). The radiocarbon dates and the age model obtained for the MM2 core are presented in Appendix 1.

At the beginning of the sequence, the sandy barrier that delimited the lagoon was more than $1 \mathrm{~km}$ toward the sea compared to its current position (Dezileau et al. 2016). Sediments at the bottom of the core contain very few faunal remains, making the sedimentary environment difficult to characterize. La Manga reached its modern position around $5400 \mathrm{cal}$. BP. Between 5400-2400 ca.l BP, faunal remains contain in sediments characterize a lagoon environment quite open to the sea. Then, after $2400 \mathrm{cal}$. BP, the Mar Menor lagoon was becoming gradually isolated from the Mediterranean (Dezileau et al. 2016).

\section{Pollen analyses}

The protocol to extract pollen grain content from sediment is adapted from the protocol described by Faegri and Iversen (1989). For each sample, $1 \mathrm{~g}$ of sediment was treated, with one lycopod spore tablet (Batch No. 483216, 18852 spores/ pellet) added before treatment to calculate the pollen concentration (Stockmarr 1971). Extraction began with hydrochloric acid to remove carbonates and then sieving at $250 \mu \mathrm{m}$ to remove the coarser elements. It was followed by separation of the organic matter within a dense liquor bath at $20^{\circ} \mathrm{C}$ (sodium polytungstate, density 2.1). The supernatant was recovered, after centrifugation, by filtration on a $0.5 \mu \mathrm{m}$ glass fiber filter. The filter was finally removed with hydrofluoric and then hydrochloric acid to retain only the organic part of the sample. For levels particularly rich in organic matter, additional filtration was carried out on a $5 \mu \mathrm{m}$ mesh sieve.

The residue was diluted in glycerol for observation. The counting of pollen grains on each slide was carried out under a bright field optical microscope with a $\times 400$ magnification while the identification was performed at x1000 magnification. The identification of pollen grains was based on determination pollen keys (Punt 19762009, Beug 1961), pollen atlases (Reille 1992), as well as the reference collection of the palynology laboratory of the Museum national d'Histoire naturelle. For each sample, a minimum of 300 pollen grains were counted excluding spores (Ralska-Jasiewiczowa and Berglund 1986). Counting was continued beyond 300 grains if a taxon represented more than $50 \%$ of a spectrum, to reach at least 150 grains outside this dominant taxon (Heusser and Balsam 1977, Turon 1984). In order to avoid problems of covariation between Pinus and other taxa due to the high variability of this taxon and its overwhelming dominance in some spectra, the pollen proportions of the other taxa were calculated by excluding Pinus from the total pollen sum. Pollen diagrams were produced using PSIMPOL software (Bennet 1992). The zonation was carried out using the CONISS method (Grimm 1987) and the number of zones was determined using the "Broken stick" method (Bennet 1996). Detailed pollen diagram are shown in Figure $2 a$ and $2 b$. The most representative pollen taxa and seven groups 
of ecological affinities for the less abundant pollen taxa have been defined to draw a simplified pollen diagram 163 (Figure 3):

- Most representative pollen taxa : Pinus, Quercus robur type, Quercus ilex type, Quercus suber type, Pistacia, Ericaceae, Phillyrea, Cistus, Chamaerops, Olea, Castanea, Juglans, Vitis, Poaceae, Plantago, Plantago lanceolata type, Rumex, Artemisia, Amaranthaceae.

- Other conifers: Abies, Cedrus and Picea markers of rare and very distant contributions.

- Riparians: Alnus, Fraxinus type excelsior, Populus, Salix.

- Other Mesophilous: Betula, Corylus, Ulmus, Acer, Carpinus, Tilia, Fagus, Hedera, Buxus.

- Other Mediterranean shrubs: Cupressaceae, Rhamnus, Viburnum.

- Other Xerophilous: Asphodelus, Asteroideae, Cichorioideae, Ephedrafragilis type, Euphorbiaceae, Tamarix, Thymeleaceae.

- Aquatic: Alismataceae, Cyperaceae, Nympheaceae, Typha/Sparganium.

- Other herbaceous: All other herbaceous taxa not represented individually in the simplified diagrams or included in one of the previous categories.

\section{$\underline{\text { Geochemical analysis }}$}

In order to obtain the lead concentration in the sediments, elemental geochemical analyses by energydispersive X-ray fluorescence (XRF) spectrometry were undertaken on wet sediments with a hand-held Niton XL3t (Dezileau et al. In prep). Measurements were realized with a step size of $1 \mathrm{~cm}$ along the core. The elemental analyses from XRF measurement were performed in mining-type ModCFprolene mode. These data directly show concentrations in ppm or percentage values. This is a semi-quantitative measurement. International powder standards (NIST2702 and NIST2781) were used to assess the analytical error and accuracy of measurement, which is lower than $5 \%$ for lead $(\mathrm{Pb})$. 


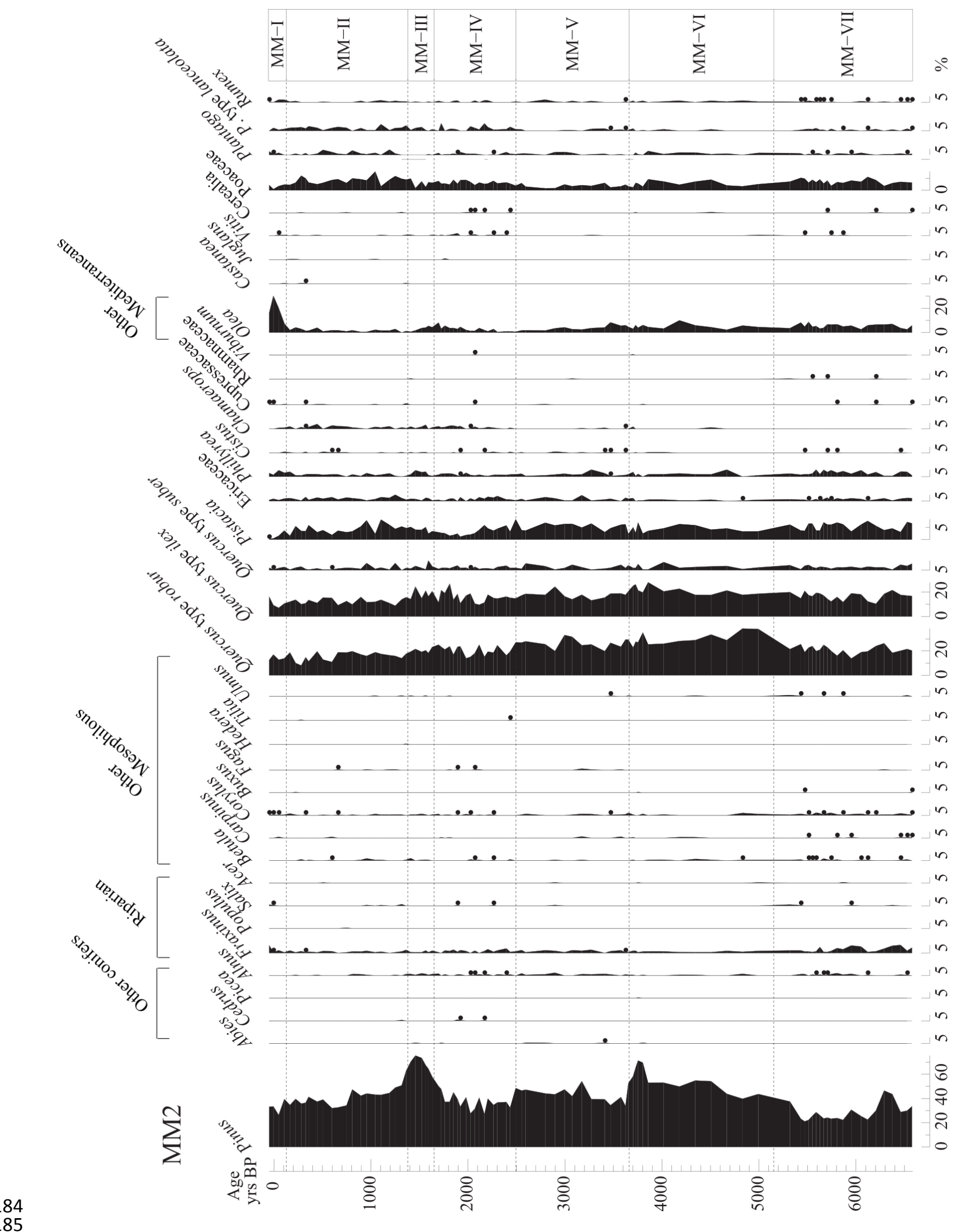

186 Figure 2a: Detailed pollen diagram of MM2 sequence (first part) 


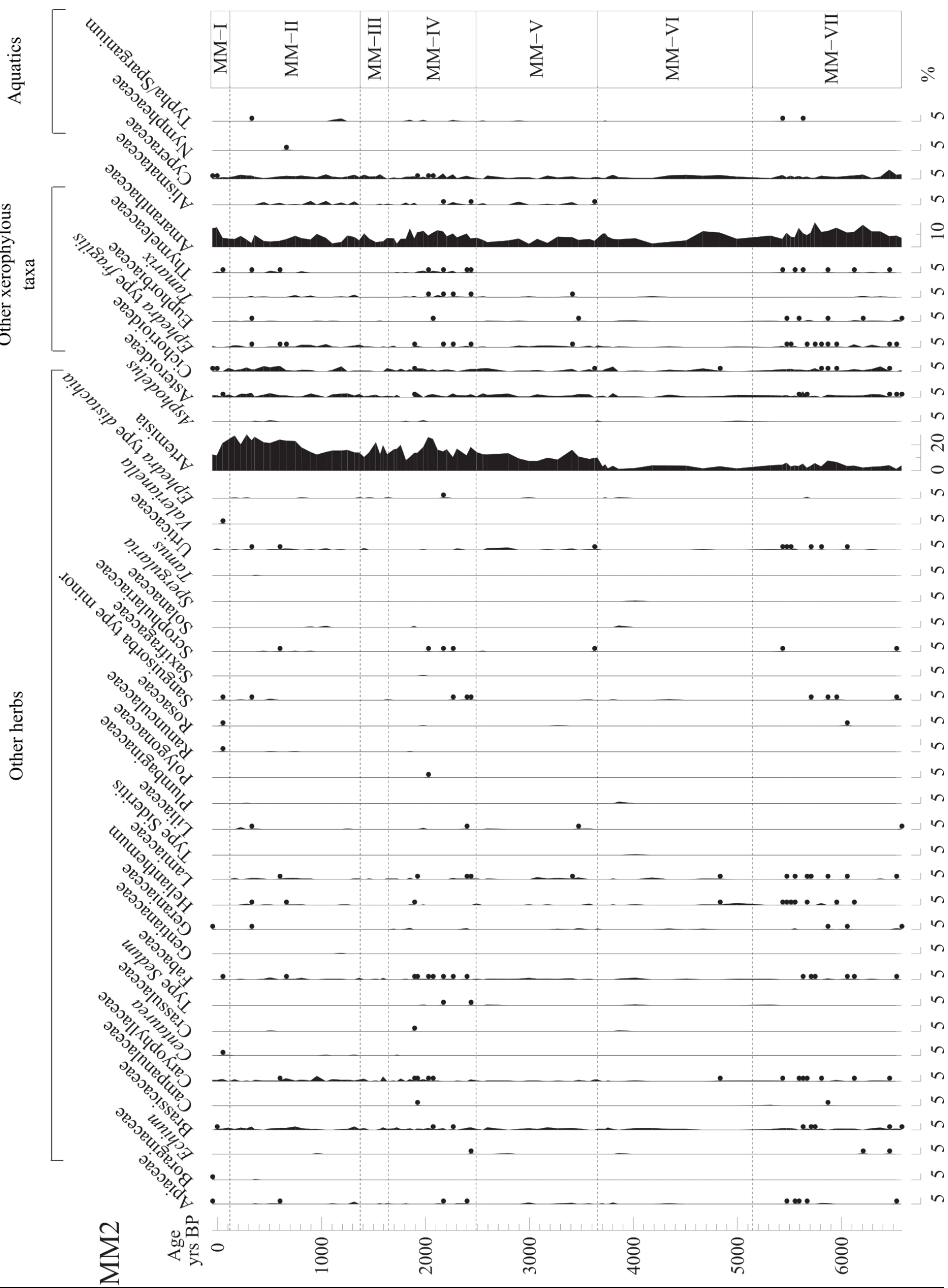

189 Figure b: Detailed pollen diagram of MM2 core (second part) 


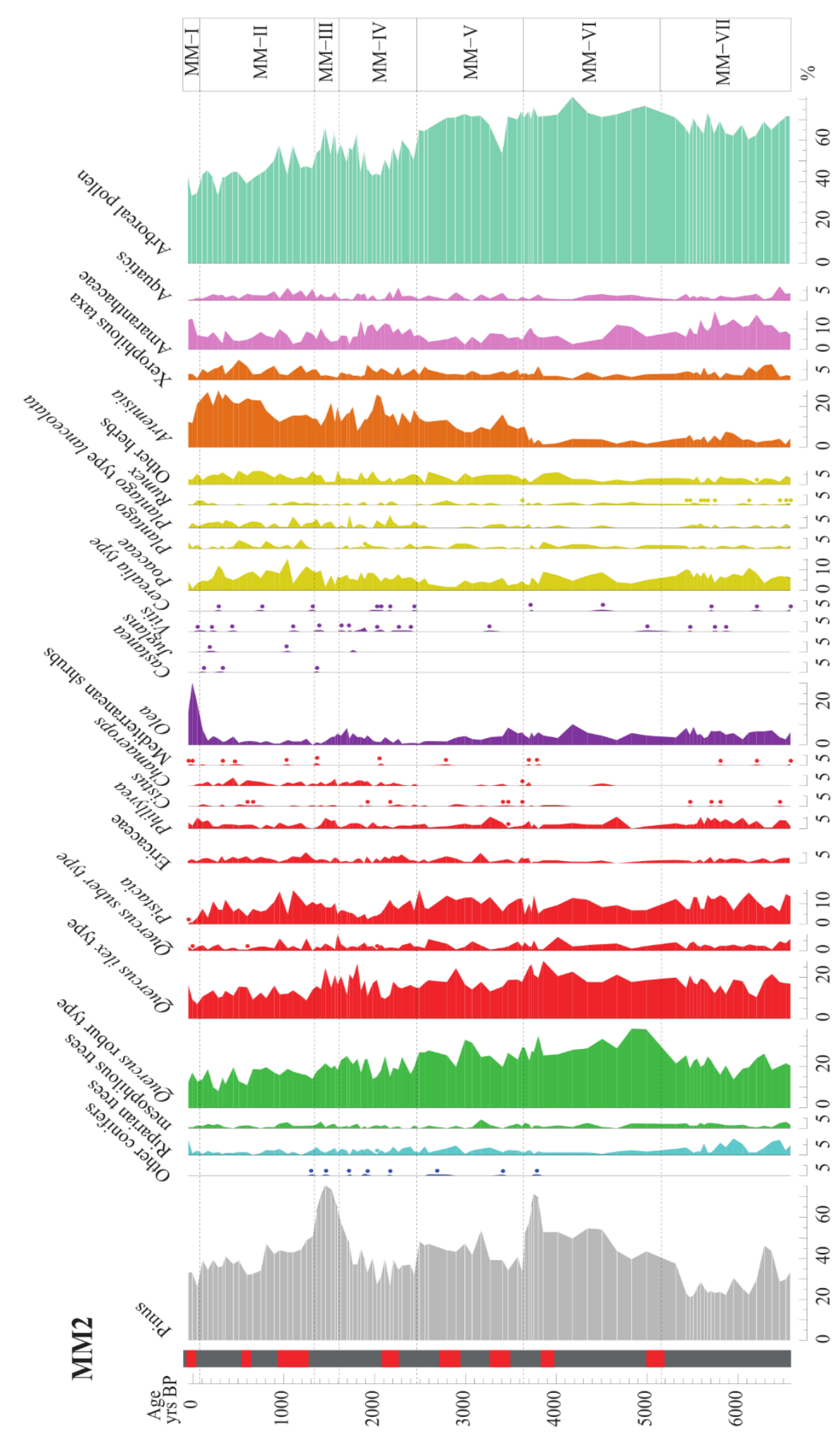

Figure 3 (color): Simplified pollen diagram of the Mar Menor sequence. On the left the stratigraphy is represented in a simplified way (grey: clayey-silt levels, red: sandy levels of storm periods). Pollen taxa are grouped according to their ecological affinities with grey/Pinus, light blue/riparian taxa, green/mesophilous taxa, red/Mediterranean shrubs taxa, purple/cultivated taxa (Olea is included in this category even though it is not widely cultivated in the region before the Classical antiquity, see discussion), yellow/herbaceous taxa, orange/xerophilous taxa, pink purple aquatic and halophyte taxa. 


\section{Results}

The Mar Menor pollen sequence consists of 93 samples forming a continuous series that covers the last 6600 years with an average timestep between two samples of 70 years (Figure 3). The preservation of pollen grains is good with an average pollen concentration of 20130 grains. $^{-1}$.

A total of 79 pollen taxa have been recorded all over the Mar Menor sequence. Pinus largely dominates most of the spectra throughout the record, with proportions ranging from 20 to $75 \%$ (Figure 3). The composition of the spectra calculated excluding Pinus shows a relatively balanced composition between trees and shrubs mainly represented by Quercus robur type, Quercus ilex type, Pistacia and Olea on the one hand, and grasses mainly represented by Artemisia, Poaceae and Amaranthaceae on the other hand (Figure 3). The automatic zonation of the diagram using the CONISS (Grim 1987) and "Broken stick" (Bennet 1996) methods made it possible to define seven significant zones for the Mar Menor sequence. Table 1 provides a brief description of each zone.

Table 1 : Description of the pollen zones of the diagram

$\begin{array}{llll}\text { Name } & \text { Depth }(\mathbf{c m}) & \text { Dates }(\text { cal. BP) } & \text { Description } \\ & & \\ & & \begin{array}{l}\text { High arboreal pollen proportions, Quercus robur type } \\ (15-20 \%), \text { Quercus ilex type }(15-20 \%), \text { Pistacia }(7-15\end{array} \\ \text { MM -VII } & 290-397 & 6580-5160 & \begin{array}{l}\%) \text { and Olea }(3-8 \%) \text { well represented, Amaranthaceae } \\ \text { relatively abundant }(\sim 10 \%) .\end{array}\end{array}$

MM -VI $\quad 215-290 \quad 5160-3640$

Pinus increases from 40 to $70 \%$, Quercus robur type (25-35\%) and Q. ilex type ( 20\%) maxima, Olea and Pistacia ( 5\%), Artemisia low proportions (>5\%).

Artemisia rises around 3650 years cal BP (x2), MM -V 152-215 $3640-2460 \quad$ Poaceae low $(<5 \%)$, arboreal pollen falls but no clear trends on individual taxa except for Olea.

Low Pinus proportions ( $35 \%)$, Pistacia fall $(10 \rightarrow 3$

MM -IV 98-152 2460-1710 $\%)$, Olea rises $(0.5 \rightarrow 5 \%)$

MM-III $\quad 68-98 \quad 1710-1340$

MM-II $\quad 10-68$
Pinus maximum (70-75 \%), arboreal pollen and shrubs increases, Olea fall $(8 \rightarrow 1 \%)$.

Pinus increases from 60 to $40 \%$ and Artemisia from 15 to $30 \%$ ), minimum arboreal pollen proportions (25$35 \%)$.

Olea increases from 2 to $30 \%$ followed by a decrease (-15\%), Quercus ilex type increases from 7 to $15 \%$ and Artemisia falls from 25 to $12 \%$.

\section{Discussion}

Origin of pollen inputs within the Mar Menor lagoon nowadays 
The comparison of the present spectrum from the core top (Figure 4) with the vegetation of the Murcia region allows us to discuss the origin of pollen inputs within the Mar Menor lagoon nowadays. Pines are the best represented taxon in the spectrum with 33\%. However, they are currently very abundant in the region (Aleppo Pine up to $1500 \mathrm{~m}$ altitude and Salzmann Pine at higher altitudes) and are important pollen producers. This percentage is therefore perfectly consistent with the regional vegetation and does not indicate an overrepresentation of this taxon. Halophyte (Amaranthaceae) and riparian vegetations (Salix and Fraxinus) along the lagoon and its tributaries represent only $15 \%$ of the spectrum. On the other hand, evergreen oaks, Mediterranean shrubs, xerophilous herbs (mainly Artemisia) and other herbaceous plants (mainly Poaceae) from the more or less open shrublands in the thermo and meso Mediterranean belts represent together 33\% of the spectrum (respectively 12, 3.5, 10.5 and 7\%). The proportions of deciduous oak pollen from the distant forest formations in the meso and supra-Mediterranean belt reach $8 \%$. All these results suggest a regional, rather than local vegetation record with mainly aerial pollen inputs. This is consistent with sedimentological analyses that do not show any significant marine or fluvial influence at the end of the sequence and the very large size of the lagoon, which theoretically implies a very large pollen source area (Sugita 2007, Azuara et al. 2019). The agricultural areas that now cover almost the entire Campo de Cartagena are only visible through the presence of Olea pollen, some of which probably also comes from wild olive trees. The dominant fruit and vegetable crops are not recorded. Finally, the hottest and driest environments in the lower thermo-mediterranean region are not recorded either. The most characteristic taxa of these environments, such as Ziziphus lotus, Periploca angustifolia or Maytenus senegalensis subsp. europaeus, are absolutely absent in relation to their very low pollen productivity (Carrión 2002a).

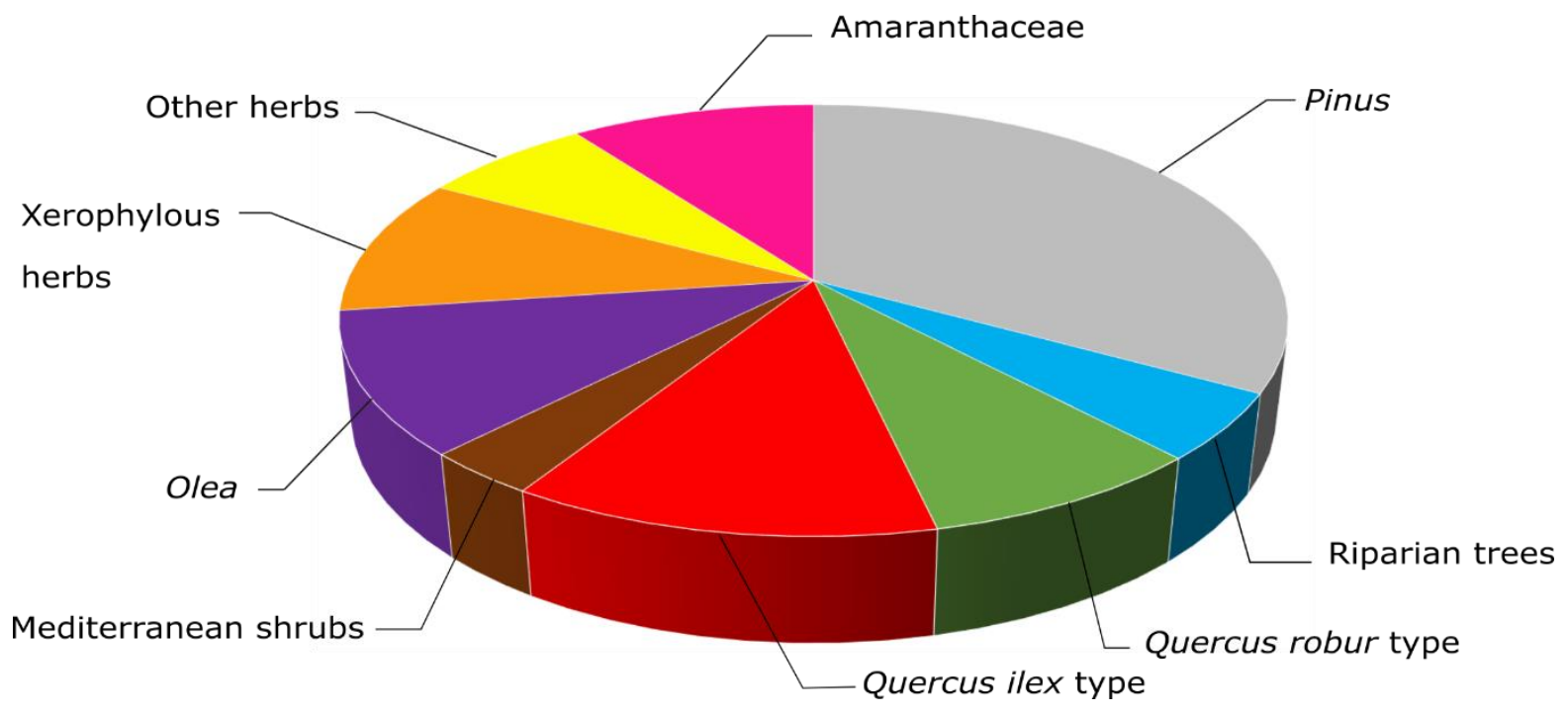

Figure 4 (color): Simplified present pollen spectrum of Mar Menor lagoon.

\section{$\underline{\text { Influence of sedimentation on pollen record }}$}

Sedimentation changes must be controlled as they may impact the integrity of the pollen assemblages and the reliability of the results in terms of vegetation changes. A very rapid increase in the proportions of Quercus robur type (deciduous oaks) and Pinus pollen is recorded around 5400 years cal BP, followed by a gradual decrease and then a sudden drop around 2400 years cal BP (Figure 3). However, during this interval, a clear marine influence is precisely recorded by the faunal remains contained in the sediments (Dezileau et al. 2016). It was around 5400 years BP that the sandy barrier separating the lagoon from the Mediterranean stabilizes around its current position near the coring site. Then around 2400 years cal BP, communications between the lagoon and the sea were interrupted. Consequently, the higher proportions of Quercus robur type and Pinus 
between these two dates probably reflect enhanced marine influences and not vegetation changes. Indeed, marine pollen sequences from this part of the Mediterranean similarly display higher proportions of these two taxa compared with continental coastal sequences (Combourieu-Nebout et al. 2009, Fletcher et al. 2013). On the other hand, since the sedimentary environment remains stable during this period and pollen concentrations remain very high (10 000-35000 grains. $\left.\mathrm{g}^{-1}\right)$, there is no reason to suspect that pollen data are not reliable. Moreover, an examination of the variations of the other taxa around 5400 and 2400 cal BP shows that only Pinus and Quercus robur type appear to be visibly affected by this bias. No other taxa show sudden and significant variations towards these dates (Figure 3).

The influence of marine storms on the pollen record was also controlled by plotting the position of sandy levels in the simplified pollen diagram (Figure 3). No anomalies related to storm levels are visible on any taxon. Detailed examination of the sequence does not show any sudden and recurrent variations in spectra that could be associated with these sedimentary events. Then, aside from the variations of Quercus robur type and Pinus proportions around 5400 and 2400 years cal BP, the other variations observed in the Mar Menor pollen sequence can therefore be related to vegetation changes and not to pollen taphonomic processes.

\section{Climate influence on vegetation changes}

The increasing aridity of the Mediterranean climate during the second part of the Holocene has been identified in many pollen sequences from south-eastern Spain. This increasing aridity is evident by gradual vegetation changes beginning between 6000-4500 years cal BP in several sites (Carrión et al. 2001, Jimez-Moreno and Anderson 2012, Jiménez-Moreno et al. 2015, Ramos-Roman et al. 2016, 2018a, 2018b) as well as in the form of more brutal transitions at variable dates: around 5200 years BP at Siles (Carrión 2002b), around 5000 years cal BP at San Rafael (Pantaléon-Cano 2003), between 4000 and 4500 at Elx (Burjachs 2012) and finally around 4000 years cal BP in Gador (Carrión et al. 2003). It might also have played a crucial role in major and very rapid vegetation transitions in the near Balearic Islands before any permanent human occupations between 5800 and 4600 cal. BP (Burjachs et al. 2017).

In the Mar Menor sequence, between 5000 and 4200 years cal BP, the proportions of Quercus robur type (deciduous oaks) gradually decrease in favor of Pinus (pines) proportions which increase by more than $10 \%$ (Figure 3). Such substitution of deciduous oaks for pines is also observed in the Siles and Gador pollen sequences (Carrión 2002b, Carrión et al. 2003) (Figure 1). In these two sequences, the correlation between pollen, microcharcoals and Pseudoschizaea, a "non pollen palynomorph" (NPP) indicator of soil erosion and used as an aridity marker in this case, shows that this vegetation change is related to increasing aridity and increased fire frequency (Carrión 2002b, Carrión et al. 2003). However, since these last two proxies have not been studied in the Mar Menor sequence, it is difficult to address the causes of this partial substitution of deciduous oak for pines, especially since these variations lie within the time window of enhanced marine influence within the lagoon, leading to an obvious bias for these two taxa.

On the other hand, the proportions of Artemisia that were relatively low $(<5 \%)$ at the beginning of the sequence suddenly rise to around 10\% at ca. 3800 years cal BP and then keep rising to reach 20\% (Figure 3). Such an increase reminds of the abrupt transitions registered in some regional sequences towards a more xerophytic vegetation (Carrión 2002b, Carrión et al. 2003), especially in the near coastal sequence of San Rafael (Figure 1) where a similar increase in Artemisia is also recorded around 5000 years cal BP (Pantaléon-Cano 2003). However, the interpretation of this last vegetation change is rather unambiguous. The sudden increase in Artemisia observed in the Mar Menor sequence occurs 1000 years later than in the San Rafael sequence which is only 160 kilometers further south. Moreover, it is concomitant with major changes in the archeological records during the Bronze Age. Thus, in this specific case, Artemisia is more likely to record anthropogenic impact than climate changes. This hypothesis will be discussed later in further detail.

As with the long term aridification trend, the shorter-scale aridity crises observed in many pollen sequences in south-eastern Spain and the Balearic Islands (Carrión 2002b, Jiménez-Moreno et al. 2015, Burjachs et al. 2017, 
Ramos-Roman et al. 2016, 2018a, 2018b) do not seem to have any obvious impact in the Mar Menor record. Indeed, none of these events seems to lead to a particular change in vegetation. However, this does not mean that the vegetation in the Mar Menor region did'nt respond to climate change. The absence in the pollen record of low pollen producing taxa from the driest environments of the lower thermo-Mediterranean level (Maytena, Periploca, Ziziphus,...) together with the ubiquity of pines and evergreen oaks in the Murcia region could explain the inability to extract a clear climatic signal. Other proxies such as NPPs or additional data analyses are needed to go further on these issues. Moreover, it is also possible that the impact of human activities was so great that it completely masks the effects of climate variability on vegetation. Thus, we will now compare the pollen record with the archeological and historical records.

\section{Impact of human activities on vegetation}

\section{Neolithic period}

In the Murcia region, the Neolithic period begins more than 7500 years ago (mid 6th millennium BC) and ends around 5000 years cal BP (Martínez-Sánchez and San Nicolas-Del Toro 2003). The base of the Mar Menor sequence is dated around 6600 years cal BP. Thus, only the final part of the Neolithic is recorded. Between 6600 and 5000 years cal BP, vegetation does not change significantly. Only an isolated peak of Pinus, Quercus robur type and Quercus ilex is observed around 6400 years cal BP (Figure 3). However, its position at the beginning of the sequence makes it difficult to interpret.

The presence of cereal pollen (Cerealia type) in three samples from this period is particularly remarkable, given the size of the lagoon and the low representation of this taxa throughout the sequence (Figure 3). These pollen grains certainly indicate the presence of cereal crops near the lagoon during the Neolithic period. Indeed, the very low representation of cultivated grasses in pollen records and the very large size of the lagoon make the Cerealia type one of the most tenuous pollen indicators of agriculture to be recorded in this type of context. This Neolithic cereal cultivation index is perfectly consistent with the archaeological record attesting to human occupation at the edge of the lagoon directly on the sandy barrier at that time, with the nearby site of Las Amoladeras reported to the final Neolithic (Garcia-Del Toro 1987).

Finally, four occurrences of Vitis pollen grains (grapevine) are recorded between 6000 and 5000 years cal BP, after that this taxon did not reappear regularly before Classical Antiquity (Figure 3). Since there is no archaeological evidence of grapevine cultivation in south-eastern Spain before the Iron Age (Precioso-Arevalo and Rivera Nuñez 2005), the Vitis pollen grains identified in Mar Menor in the late Neolithic most certainly comes from wild vines (Vitis vinifera subsp. sylvestris). However, the very arid conditions around the lagoon today do not allow the development of this species, which is found only further inland (Sanchez-Gomez et al. 1998) and the Vitis pollen grains, like the Cerealia type, are generally poorly recorded in pollen sequences because vines are very poor pollen disperser (Turner and Brown 2004). Therefore, their identification in Mar Menor could suggest that wild grapevines were growing locally. It would imply that the climate at that time was sufficiently humid near the coast to allow wild grapevines to grow spontaneously, which is consistent with regional pollen data showing during that period the maximum development of mesophilic forests in the massifs (Carrión 2002b, Carrión et al. 2001, 2003, 2007). Moreover, human populations could also have favored its establishment near occupation sites by cultivation of vines which seeds morphology had not been influenced by domestication or simply by seed dispersal due to regular consumption as wild vines are zoochorous plants. Both hypothesis are plausible when considering the grapevine seeds found in archaeological contexts in several Neolithic sites in Catalonia and south-eastern Spain, which attests to early exploitation of wild grapevines in the Iberian Peninsula (Precioso-Arevalo and Rivera Nuñez 2005). 
In the Murcia region, the first Chalcolithic occupations of "Los Millares" culture began around 5000 years cal other significant change in vegetation is visible during the Chalcolithic period (Figure 3). However, the Neolithic/Chalcolithic transition is difficult to study from Mar Menor sequence. Pollen spectra are biased around 5400 years cal BP due to the stabilization of the sandy barrier inducing an increase in Pinus and Quercus robur type. In addition, the temporal resolution around 5000 years cal BP is low due to a storm level that does not allow an adequate sampling in this part of the core.

On the other hand, this absence of vegetation change during the Chalcolithic period in the Mar Menor sequence is not an isolated observation. The Baza pollen sequence, located about $200 \mathrm{~km}$ to the south in the Sierra de los Filabres (Figure 1), has also been compared in detail with a very extensive archaeological record (Carrión et al. 2007). Examination of the Chalcolithic period shows a remarkably stable vegetation throughout this time period despite numerous and very well documented human occupations. Thus, it would appear that the Chalcolithic populations of south-eastern Spain have had a rather moderate or at least local impact on their environment which was therefore not recorded at the regional scale. It is also possible that the forest ecosystems of this period were resilient enough to absorb the disruptions induced by the activities of the Chalcolithic societies that had a profound impact on the regional archaeological record (Carrión et al. 2007).

\section{The Bronze Age period}

Between 3900 and 3700 years cal BP (1950-1750 BC) major vegetation changes occurred around the Mar Menor lagoon. First, the already high proportions of Pinus increased dramatically, from $50 \%$ to $70 \%$ in only 100 years. This increase, which is not linked to any sedimentary events, indicates a significant expansion of pioneer vegetation at a regional scale and therefore reflects highly disturbed landscapes. Thereafter, Pinus proportions declined by $35 \%$ in about 200 years, followed shortly after by arboreal pollen proportions (excluding pines) that decreased by $15 \%$ indicating a major deforestation (Figure 5). Simultaneously, the general composition of herbaceous vegetation also changed dramatically. Poaceae (grasses), which previously ranged from 5 to $10 \%$, became rarer while Artemisia increased by 2 to $10 \%$ (Figure 5). The study of the Sebkha Boujmel pollen sequence located in sub-desert areas of Tunisia shows that such an increase in Artemisia proportions may correspond to a degradation of meadow environments related to pastoral activities (Jaouadi et al. 2016). Indeed, some Artemisia species, in particular Artemisia campestris which is very common in the Murcia region (Sanchez-Gomez et al. 1998), are not very palatable and therefore less consumed by livestock (Gamoun and Zammouri 2014). Thus, in some environments severely degraded by grazing, Artemisia campestris can proliferate to become very abundant (Genin et al. 2006).

All these vegetation changes occured in a very short time, just after a major transition in the archaeological record, around 4200 years cal BP (2250 BC), between the Chalcolithic "Los Millares" culture and the Argar culture. The Argar culture characterizes the first part of the Bronze Age in the southeastern part of the Iberian Peninsula and occupies a very important place in the archaeological record of the Murcia region (Eiroa 2004). Comparison of pollen data with the precise chronology of the Argar period shows that almost all the vegetation changes mentioned above correspond very precisely to the Middle Argar period (Ar 2) between 3850 and 3600 years cal BP (1900-1650 BC) (Eiroa 2004). This period corresponds to the political, cultural and economic zenith of this culture. This is the period during which large sites became individualized, particularly important defensive bastions. At that time, the diversity of the occupied environments was the most important (Eiroa 2004). In the Late Argar between 3600 and 3400 cal. BP (1650-1450 BC, Ar 3), Pinus proportions stopped falling and those of Artemisia stabilized. Only the arboreal pollen proportions of trees (excluding pines) that have been fairly stable so far, fell in turn.

The pollen sequence of Baza in Andalusia also shows a very marked impact of human activities on vegetation during the Argar period, with exactly the same rate as in Mar Menor (Figure 5). Vegetation remained stable 
during the Early Argar between 4100 and 3850 years cal BP (2150-1900 BC, Ar 1), despite a slight increase in the fire signal. Very rapid deforestation and development of sclerophyllous vegetation occured during the Middle Argar ( $\operatorname{Ar} 2)$, then finally vegetation stabilized in a degraded state in the Late Argar $(\operatorname{Ar} 3)($ Carrión et al. 2007).

Finally, the lead concentration in lagoon sediments increased for the very first time in the sequence at the end of Late Argar around 1500-1400 BC (Figure 5). This lead pollution strongly supports the presumptions of mining and metallurgical activities suggested by the archaeological corpus for this period (Eiroa 2004) and is consistent with previous studies on lead pollution in this area (Manteca et al. 2017).Figure 5

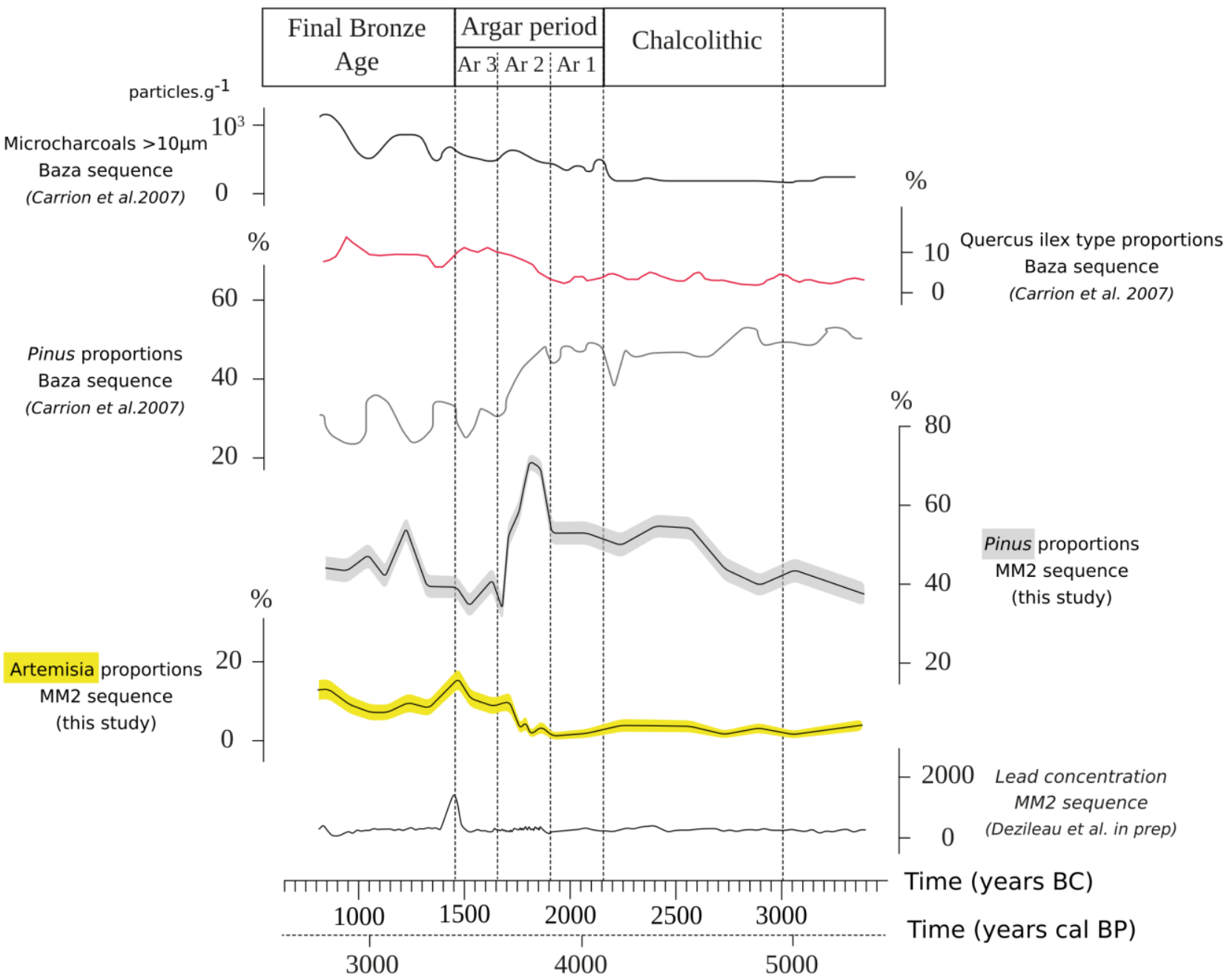

Figure 5 (color): Comparison of Mar Menor pollen data with lead concentration in MM2 core (Dezileau et al. in prep), and with pollen and microcharcoal data from the Baza sequence (Carrión et al. 2007) for the Argar period. The shaded areas around the pollen curves of Mar Menor represent the theoretical uncertainty of pollen proportions computed from a multi-nomial law (Faegri and Iversen 1989).

After the Argar period began the final Bronze Age period around 3400 years cal BP (1450 BC). The Mar Menor sequence shows a moderate increase of the proportions of Pinus and arboreal pollen (Figure 5). However, Mediterranean shrubs were more abundant and the proportions of Artemisia remained high. These observations suggest a moderate recovery of vegetation after the major changes of the Argar period. The presence of final Bronze Age sites in the region suggests that there was some continuity in anthropogenic pressure on the environments that would explain the persistence of such degraded environments. On the other hand, since Artemisia and Mediterranean shrubs are taxa of rather xerophyte affinity, it is also possible that they were also 
favoured by the increasing aridity during the second half of the Holocene. While the close coincidence between environmental degradation in the region and the development of Argar culture strongly supports a human trigger for this radical change, it cannot be ruled out that a change in climate may have been decisive in maintaining this new degraded vegetation, which is probably better adapted to frequent disturbances, regardless of their origin.

\section{Iron Age period}

The exploitation of the mining resources of the Cartagena-La Union massif during the Iberian Period (Domergue 1990), is well visible in the Mar Menor sequence through the rapidly increasing lead concentration in lagoon sediments between the beginning of the $5^{\text {th }}$ century and the settlement of Carthaginians (227 BC) (Figure 6). Unfortunately, the vegetation of this key period is difficult to study due to the closure of the lagoon at about the same time, which biases the pollen record. Nevertheless, from 3500 years cal BP, the proportions of Olea which were relatively stable around 5\% since the beginning of the sequence, gradually declined to near zero around 2400 years cal BP and only reappeared during the Classical Antiquity (Figure 3). This decrease certainly indicates a progressive scarcity of wild olive trees (Olea europea subsp. sylvestris) in thermo-Mediterranean shrub formations. This near disappearance of the wild olive tree coincides with the beginning of the regular occurrences of Chamaerops pollen grains (dwarf palm) which until then had only been represented very episodically (Figure 3). This substitution shows a late change in the composition of shrub formations that seems difficult to explain from a climatic point of view. Chamaerops humilis, the dwarf palm, may be abundant in some of the more thermophilic formations of the lower thermo-Mediterranean region. However, it is mainly found in the same environments as the wild olive tree in the Murcia region (Martinez-Parras et al. 1992). Ecological studies conducted in south-eastern Spain have shown that wild olive trees are extremely sensitive to grazing and that their disappearance could be an indicator of disturbance by pastoral activities (Alados et al. 2004, Navarro et al. 2006). The same studies also show that on the contrary, the dwarf palm is particularly resistant to moderate grazing pressure. Therefore, it seems likely that the observed change in the composition of shrub formations resulted from degradation of these environments by pastoral activities.

\section{Classical Antiquity}

The Roman conquest at the end of the third Century BC ( 2150 cal. BP), the exploitation of silver and lead mines and the very important agricultural development of this period are perfectly visible in the Mar Menor sequence. From the end of the Iberian period in the middle of the $4^{\text {th }}$ Century BC (2300 cal. BP), Olea which had almost disappeared from the pollen sequence previously, is recorded again (Figure 6). After the Carthaginian and Roman conquests, its proportions increased steadily until reaching values close to $10 \%$ in the $3^{\text {rd }}$ Century AD (1750 cal. BP) (Figure 5). In this context, and considering the historical evidence, it is reasonable to assume that this increase in Olea proportions corresponds to the major development of olive growing, which has been very well documented by historians and archaeologists in this region (Orejas and Ramallo 2004, Noguera Celdràn and Antolinos Marin 2009, 2010). At the same time, Vitis and Cerealia type were well represented throughout this period (Figure 6) considering the size of the lagoon.

Mining, on the other hand, resulted in a peak in lead concentration which could coincide with the founding of the city of Qart Hadasht (future Carthago Nova) by the Carthaginians followed by the Roman conquest after few decades, if age model errors are taking into account. Then lead concentrations remain high between the Roman conquest and the $2^{\text {nd }}$ Century $\mathrm{AD}$ (Figure 6). From an archaeological point of view, the exploitation of the galena deposits of Cartagena by the Carthaginian first and then the Romans was of such a magnitude that it has masked until a relative recent period any trace of previous exploitation. During the Republican era and then at the very beginning of the Imperial period, Carthago Nova mines were at their height. They were one of the largest producer of silver and lead in the Roman world. In the middle of the 2nd Century BC, the historian Polybe mentioned more than 40,000 workers mobilized for ore extraction (Baron et al. 2017). 
442 The pollen data allow the assessment of the impact on the vegetation of this unprecedented economic 443 development. The pollen proportions of Mediterranean shrubs, particularly Pistacia, declined sharply from the 444 Roman period onwards, clearly showing a very marked decline in shrubland formations. On the other hand, the 445 main tree taxa, in particular Pinus, Quercus robur type (deciduous oaks) and Quercus ilex type (Mediterranean 446 oaks), appear to be slightly affected. They display proportions equivalent to those observed at the end of the 447 Neolithic period (Figure 3 and 4). These elements suggest that the important development of agriculture and 448 mining activities around Carthago Noua has been to the detriment of the shrublands of the Thermo449 Mediterranean belt rather than that of the Meso-Mediterranean forests. An examination of the distribution of 450 Roman sites from the Republican and Early Imperial periods seems to confirm this observation. The listed 451 archeological sites are mainly distributed in Thermo-Mediterranean plains, such as the Campo de Cartagena, 452 the Segura and Guadalentin valleys and coastal reliefs of Carthagena-la Union and Mazarron at altitudes of less 453 than $500 \mathrm{~m}$ (Orejas and Sanchez-Palencia 2002).

454 From the second Century AD, the lead concentration in the sediments of the lagoon decreased until it returned 455 to very low values. This decrease in lead pollution was followed by a gradual decrease in Olea proportions and 456 an unprecedented increase in Pinus proportion from 40 to about $80 \%$ at the beginning of the third Century. 457 These changes indicate a significant industrial and agricultural decline in the region (Figure 6) which is perfectly 458 consistent with the historical and archaeological records that document the decline of mining and agricultural 459 activities respectively from the $2^{\text {nd }}$ and $3^{\text {rd }}$ Centuries AD. Many of the agricultural settlements related to the beginning of the Roman Empire declined and disappeared at this time (Orejas and Ramallo 2004). These abandonments particularly affected the establishments closest to the city and therefore concerned the immediate surroundings of the lagoon. Further inland in the Guadalentin Valley or the Jumilla Highlands, the rural economy was more resilient and some sites still experienced a long period of prosperity. However, even in these relatively preserved regions, agricultural activities were undergoing significant changes, including a decline in olive growing that was probably no longer profitable in the new economic context (Noguera-Celdràn and Antolinos-Marin 2009, 2010). 


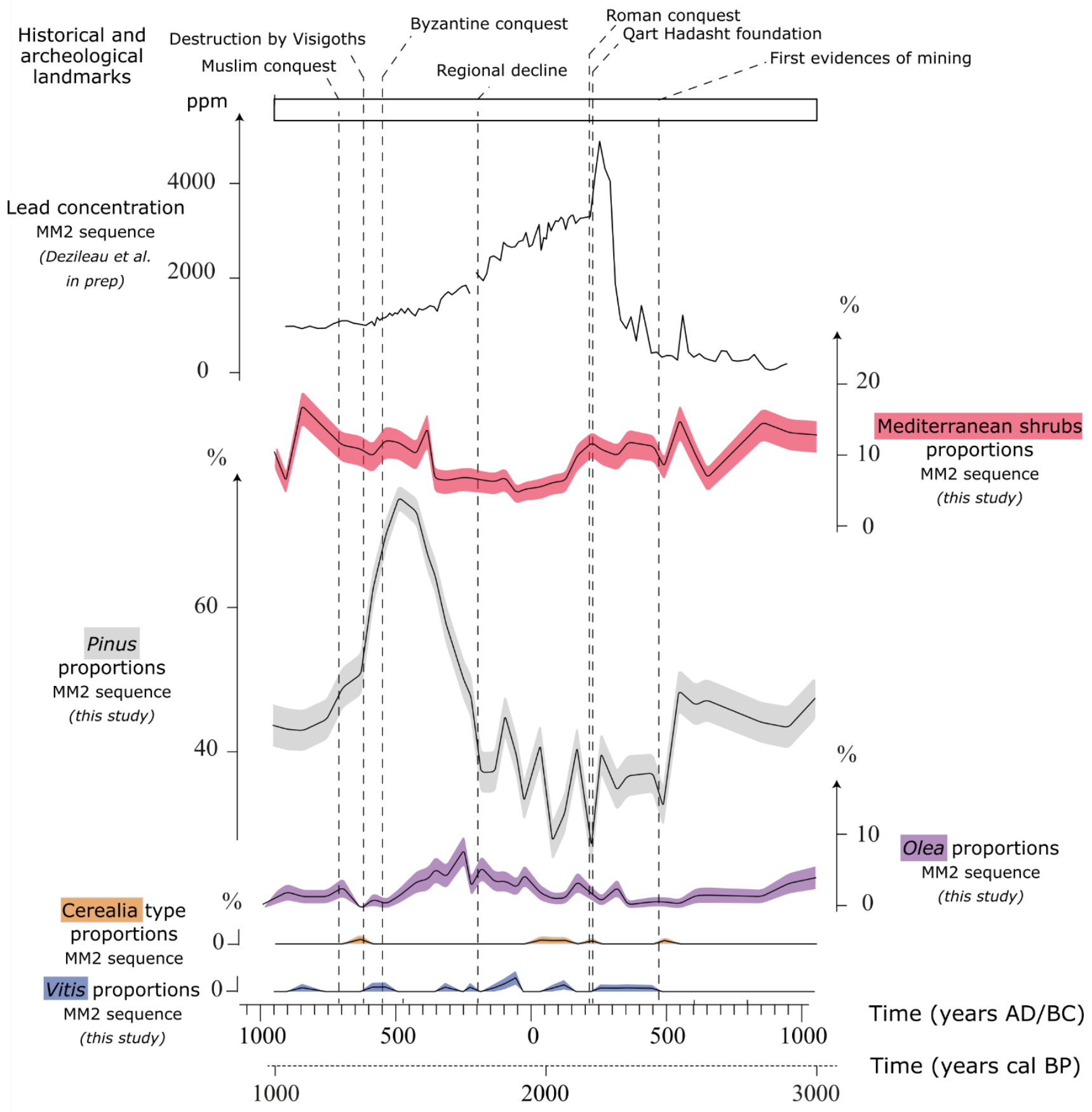

Figure 6 (color): Comparison of Mar Menor pollen data with lead concentrations in lagoon sediments and with the main historical events affecting the region for the protohistoric, Classical Antiquity and early Middle Ages. The shaded areas around the pollen curves of Mar Menor represent the theoretical uncertainty of pollen proportions computed from a multi-nomial law (Faegri and Iversen 1989).

472 The increase in Pinus proportion characterizing this economic decline is quite extraordinary. It certainly reflects 473 a rapid recolonization by Pinus halepensis (Aleppo pine) of all the abandoned land following this decline. This pioneer species, which is very well adapted to the Mediterranean summer drought, is heliophilous, disperses its seeds very efficiently and has a high growth rate (Rameau 2008). In fact, Pinus halepensis is one of the main pioneering trees in the Murcia region where it forms large stands in degraded shrublands from sea level to an altitude of 1500m (Sanchez-Gomez 1998). Agricultural and mining activities in the early Roman period mainly affected low-altitude Thermo-Mediterranean shrublands. In addition, the economic decline was particularly significant in the coastal massifs and the Campo de Cartagena, in other words, as close as possible to the lagoon. 
Consequently, the degraded shrub formations, favorable to the development of pine forests, must have been very abundant in the surroundings of Mar Menor from the 3rd Century AD, which would explain this spectacular recolonization. Pines are also very important pollen producers, so it is consistent that this change in vegetation appears clearly in the pollen record.

The Pinus proportions continued to increase until the middle of the $5^{\text {th }}$ Century AD and only then started to decrease marking the beginning of the decline of pine formations (Figure 6). This decline in Pinus proportions coincided with a renewal of the city of Cartagena and a period of economic recovery (Molina Molina 2008). It is therefore possible that this led to a new period of deforestation. However, it is also during this period that Mediterranean shrub formations, which were at their lowest since the Roman conquest, increased again to return to their previous values (Figure 6). The closure of the landscape due to the redevelopment of shrublands probably led to the disappearance of environments favorable to the germination of the heliophilous Pinus halepensis (Rameau 2008), thus explaining its decline. Furthermore, it must be considered that after the 5th Century $\mathrm{AD}$, the rural economy in the Cartagena region entered again into recession while the accelerated decline of pine forests continued until the 7th Century AD, after the destruction of the city by the Visigoths (Figure 6). These elements rather support the hypothesis of a natural regression of pines in the context of an ecological succession rather than a new deforestation. These observations therefore provide important information on the resilience of Mediterranean shrub ecosystems, in particular the time required for their regeneration. In that case, pollen data show that it takes about 100 years for Mediterranean shrublands to return to their optimum development, and another 200 years for pioneer pines to disappear from the environments they colonized, as they cannot regenerate (Figure 6). This is consistent with the life expectancy of Pinus halepensis, which is about 200 years (Rameau et al. 2008).

\section{The Muslim period}

For the Muslim period (713-1245 AD), the pollen record from Mar Menor seems to be divided in two parts. Between the 8th and 10th Centuries $\mathrm{AD}$, vegetation remained relatively stable around a composition close to that of the pre-Roman period with slightly higher proportions of Pinus and arboreal pollen (Figure 7). This is consistent with a moderate impact of human activities on vegetation, reflecting the relatively modest development of the region according to historical sources during that period. Indeed, despite the foundation of the city of Murcia by the Umayyads in $825 \mathrm{AD}$, the region remained poorly urbanized and populated mainly by the descendants of pre-Muslim populations (Jiménez-Castillo 2013). In contrast, in the 11th and 12th Centuries AD, the proportions of Pinus and arboreal pollen (excluding pine) fell rapidly while the proportions of Artemisia increased from 10 to $20 \%$ (Figure 7 ). This vegetation change probably reflects a deforestation, mainly affecting shrublands and pine forests, as well as a degradation of open environments, due to pastoralism as suggested by the increase in Artemisia at the expense of Poaceae (Genin et al. 2006, Gamoun 2014). It corresponds very precisely to the period of economic prosperity and demographic growth of the city of Murcia and its surroundings. Indeed, at that time, Al-Andalus (Muslim Spain) experienced an alternation of centralizing periods under the domination of the Almoravids (1091-1144 AD) then the Almohads (1172-1224 AD), interspersed with periods of break-up into many small independent kingdoms, the Taifas. Murcia and its surroundings considerably developed, especially during the periods of independence of the city (JiménezCastillo 2013). In the 11th and 12th Centuries AD, a vast and very complex irrigation network developed around the city of Murcia in the valley of the Segura River, the "Huerta de Murcia". It allowed the development of a diversified and intensive agriculture in a relatively large area (Jiménez-Castillo 2013). Further south, in the Campo de Cartagena, a more extensive agriculture was developing in the absence of irrigation systems. Water reservoirs, wells and facilities to take advantage of irregular ramblas inflows were built to partially compensate for the aridity of this plain. However, most of this area was more likely to be under non-irrigated and livestock cultivation (Jiménez-Castillo 2013). 


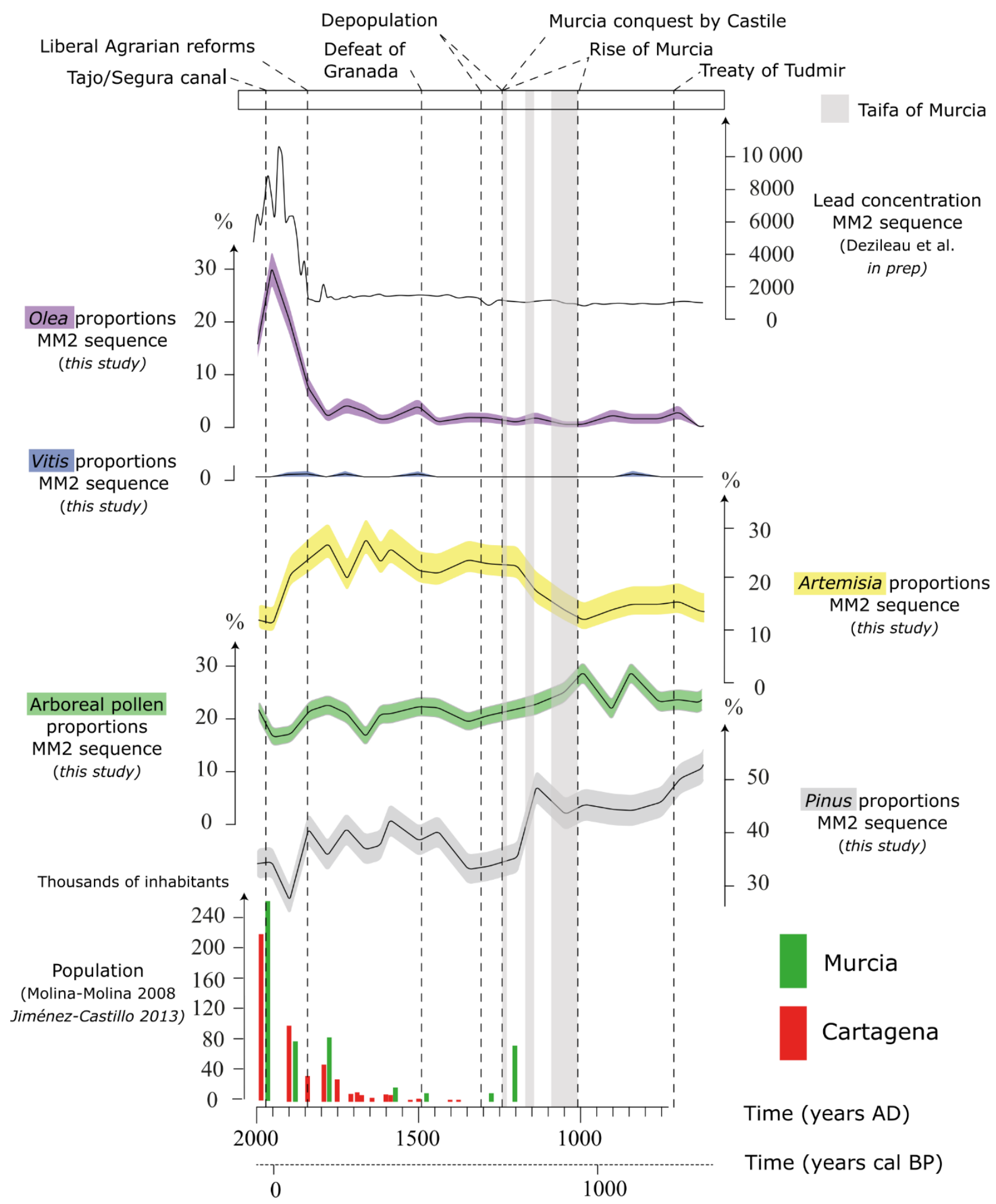

Figure 7 (color): Comparison of pollen data from the Mar Menor sequence with the lead concentration of lagoon sediments and with population data for the cities of Murcia and Cartagena from the $13^{\text {th }}$ and $15^{\text {th }}$ centuries respectively to the modern period. The shaded areas around the pollen curves of Mar Menor represent the theoretical uncertainty of pollen proportions computed from a multi-nomial law (Faegri and Iversen 1989). 
533 From the middle of the $13^{\text {th }}$ Century to the $19^{\text {th }}$ Century, the proportions of Pinus and Arboreal pollen (excluding pines) remained low, while Artemisia proportions stabilized around very high values (20-25\%) (Figure 7). The pollen record does not show any reforestation or vegetation recovery, even though the region was losing a large part of its inhabitants (Figure 7). Indeed, the Murcia region was experiencing a major and lasting crisis. The middle of the 13th Century marked the end of Muslim domination in this region, and in 1243 the city of Murcia became a Castilian protectorate. After that, the harshly repressed revolt of the Muslim populations in 1264, the internal wars within the Christian camp, and the resistance of the kingdom of Granada against Christians (which turned the Murcia region into a border zone) led to episodes of mass exodus one after the other and gradually emptied the area of its inhabitants (Jiménez-Castillo 2013). During the second half of the 13th Century, the population of the city of Murcia decreased from 70,000 to 10,000 inhabitants (Manzano- Martínez 2002). This general depopulation particularly affected the coast, which was regularly threatened by raids of Barbary privateers (Torres-Fontes 1976, Molina-Molina 2008). However, historical data show that these neglected territories were not completely abandoned (Lillo 1981, Eiroa 1986, Pérez-Ruzafa et al. 1987). A highly specialized regional economy almost exclusively oriented towards extensive livestock farming developed, explaining the low Pinus and arboreal pollen proportions coinciding with the high proportions of Artemisia. Moreover, at the very end of the 15th Century AD, after the fall of the kingdom of Granada, the large and powerful herd owners who had prospered for the last 200 years influenced the councils in charge of land redistribution after the end of the Christian conquest in order to protect their interests (Molina-Molina and Jiménez Alcazar 1996). Therefore, the region remained occupied by vast areas of pasture until the $19^{\text {th }}$ Century, which is consistent with the pollen data showing the highest Artemisia proportions of the sequence (20-30\%).

\section{The Late Modern Period}

From the 19th Century onwards, the proportions of Olea increased dramatically (from around 5 to 30\%) while the proportions of Artemisia were divided by two and the proportions of Pinus and arboreal pollen also decreased (Figure 7). These vegetation changes at the regional scale were linked to profound changes in the economy of the Murcia region. Political reforms (liberal agrarian reforms) put an end to the extensive livestock farming that had been going on since the 13th Century. It gave way to pig and goat farms with a much more limited territorial hold, while non-irrigated agriculture, with cereals, vines, olives, almonds, figs and carob trees, was invading the territory (Pérez-Picazo and Lemeunier 1990). The 19th Century AD was also the period of resumption of mining activities around Cartagena, which saw its population explode (Vilar et al. 1985) (Figure 7). In 1907 AD, 1151 mining concessions were exploited in the Cartagena-La Union massif (Baron et al 2017). This new mining activity is perfectly recorded by the evolution of the lead concentration in the sediments of the lagoon (Figure 7). It is probably one of the main causes of deforestation highlighted by the decline in Pinus and arboreal pollen proportions (excluding pines) (Figure 7). Indeed, agricultural development during this period was essentially the result of a transformation of activities on land already in use and probably had little impact on this clearing (Pérez-Picazo and Lemeunier 1990).

Finally, the Olea proportions are divided by two at the end of the Mar Menor sequence during the second half of the $20^{\text {th }}$ Century. This final drop in Olea proportions corresponds to the development of intensive agriculture which began in the 1950s and accelerated greatly in the 1980s after the construction of the Tajo-Segura canal. Olive, almond and cereal crops then declined sharply in favour of fruit trees and market gardening (Pérez-Picazo and Lemeunier 1990).

\section{Conclusion}

The MM2 core from the Mar Menor lagoon in the Murcia region has provided a high-resolution pollen record covering the last 6500 years. Some elements in the sequence could suggest an influence of climate fluctuations on the vegetation; yet their interpretation remains ambiguous. Such difficulties in recording a climate signal could be related to the low representation of the driest environments of the Thermo-Mediterranean belt and/or 
to the ubiquity of pines and evergreen oaks in the Murcia region together with the very important impact of human activities on the vegetation. Further work including complementary proxies and finer data analysis will have to be investigated to better address this issue. On the other hand, the comparison with archaeological and historical records makes it possible to highlight a vegetation history strongly linked to human occupations. The Argar period in the Bronze Age, the Classical Antiquity and finally the Modern Period are the three key archaological and historical periods of this sequence in terms of human impact. Pinus (probably Pinus halepensis) is the pollen taxon which best records this signal of anthropogenic impact. Pines have been a major component of the ecosystem of the Murcia region for at least 6500 years, and appear to have been extremely sensitive to land-use changes. The Mar Menor sequence provides very interesting elements to investigate the resilience of semi-arid ecosystems to anthropogenic disturbances. Interdisciplinary approaches combining the comparison of the observed vegetation dynamics with detailed archeological and historical data and results of ecosystems modeling could be of great interest to better understand the mechanisms involved in these vegetation changes.

\section{Acknowledgements}

This research was funded by MISTRALS/PALEOMEX meta-program, the CNRS and the French Museum of National History (). Pollen samples were processed at the UMR 7194 CNRS and pollen data are available from J. Azuara. We are grateful to the editor and the reviewers for their remarks and comments which have helped to improve this article. None of the authors have conflicts of interest to declare.

\section{References}

Alados, C.L., ElAich, A., Papanastasis, V.P., Ozbek, H., Navarro, T., Freitas, H., Vrahnakis, M., Larrosi, D., Cabezudo, B., 2004. Change in plant spatial patterns and diversity along the successional gradient of Mediterranean grazing ecosystems. Ecological Modelling 180, 523-535. https://doi.org/10.1016/j.ecolmodel.2003.10.034

Azuara, J., Combourieu-Nebout, N., Lebreton, V., Mazier, F., Müller, S.D., Dezileau, L., 2015. Late Holocene vegetation changes in relation with climate fluctuations and human activity in Languedoc (southern France). Climate of the Past 11, 1769-1784.

Azuara, J., Mazier, F., Lebreton, V., Sugita, S., Viovy, N., Combourieu-Nebout, N., 2019. Extending the applicability of the REVEALS model for pollen-based vegetation reconstructions to coastal lagoons. The Holocene 29, 1109-1112. https://doi.org/10.1177/0959683619838024

Baron, S., Rico, C., Marín, J.A.A., 2017. Le complexe d'ateliers du Cabezo del Pino (Sierra Minera de Cartagena-La Unión, Murcia) et l'organisation de l'activité minière à Carthago Noua à la fin de la République romaine. Apports croisés de l'archéologie et de la géochimie. Archivo Español de Arqueología 90, 147-169.

Bennett, K.D., 1992. PSIMPOLL: a quickBASIC program that generates PostScript page description files of pollen diagrams. INQUA Commission for the study of the Holocene: working group on data handling methods newsletter 8, 11-12.

Bennett, K.D., 1996. Determination of the number of zones in a biostratigraphical sequence. New Phytologist 132, 155-170.

Beug, H.-J., 1961. Leitfaden der pollenbestimmung. Fischer, Stuttgart 1, 63.

Boucher, C., 1988. Carte de la vegetation potentielle de la Sierra de Cazorla (Andalousie, Espagne). Documents de Cartographie Ecologique 31, 25-36.

Burjachs, F., 2012. n.d. Elx, in: Paleoflora y Paleovegetación de La Península Ibérica e Islas Baleares: Plioceno-Cuaternario. pp. 647-648.

Burjachs, F., Pérez-Obiol, R., Picornell-Gelabert, L., Revelles, J., Servera-Vives, G., Expósito, I., Yll, E.-I., 2017. Overview of environmental changes and human colonization in the Balearic Islands (Western Mediterranean) and their impacts on vegetation composition during the Holocene. Journal of Archaeological Science: Reports 12, 845-859. 
Carrión, J.S., 2002a. A taphonomic study of modern pollen assemblages from dung and surface sediments in arid environments of Spain. Review of Palaeobotany and Palynology 120, 217-232.

Carrión, J.S., 2002b. Patterns and processes of Late Quaternary environmental change in a montane region of southwestern Europe. Quaternary Science Reviews 21, 2047-2066.

Carrión, J.S., Van Geel, B., 1999. Fine-resolution Upper Weichselian and Holocene palynological record from Navarrés (Valencia, Spain) and a discussion about factors of Mediterranean forest succession. Review of Palaeobotany and Palynology 106, 209-236.

Carrión, J.S., Andrade, A., Bennett, K.D., Navarro, C., Munuera, M., 2001. Crossing forest thresholds: inertia and collapse in a Holocene sequence from south-central Spain. The Holocene 11, 635653.

Carrión, J.S., Sánchez-Gómez, P., Mota, J.F., Yll, R., Chaín, C., 2003. Holocene vegetation dynamics, fire and grazing in the Sierra de Gádor, southern Spain. The Holocene 13, 839-849.

Carrión, J.S., Fuentes, N., González-Sampériz, P., Sánchez Quirante, L., Finlayson, J.C., Fernández, S., Andrade, A., 2007. Holocene environmental change in a montane region of southern Europe with a long history of human settlement. Quaternary Science Reviews 26, 1455-1475. https://doi.org/10.1016/j.quascirev.2007.03.013

Combourieu Nebout, N., Peyron, O., Dormoy, I., Desprat, S., Beaudouin, C., Kotthoff, U., Marret, F., 2009. Rapid climatic variability in the west Mediterranean during the last 25000 years from high resolution pollen data. Climate of the Past 5, 503-521.

Dezileau, L., Pérez-Ruzafa, A., Blanchemanche, P., Degeai, J.-P., Raji, O., Martinez, P., Marcos, C., Von Grafenstein, U., 2016. Extreme storms during the last 6500 years from lagoonal sedimentary archives in the Mar Menor (SE Spain). Climate of the Past 12, 1389-1400. https://doi.org/10.5194/cp-12-1389-2016

Domergue, C., 1990. Les mines de la Péninsule Ibérique dans l'antiquité romaine. Ecole française de Rome. 625 pp.

Eiroa, J.J., 2004. La edad del bronce en Murcia. Real Academia Alfonso X el Sabio. Murcia. 197 pp.

Eiroa, J.J., 1986. Aproximación a los modelos sociales de la Edad del Bronce en el Sureste. In: Mas, J. (Ed.), Historia de Cartagena II, 353-404.

Faegri, K., Iversen, J., 1989. Textbook of pollen analysis (4th edn by Faegri, K., Kaland, PE \& Krzywinski, K.). Wiley, Chichester.

Fletcher, W.J., Debret, M., Goñi, M.F.S., 2013. Mid-Holocene emergence of a low-frequency millennial oscillation in western Mediterranean climate: Implications for past dynamics of the North Atlantic atmospheric westerlies. The Holocene 23, 153-166.

Gamoun, M., Zammouri, J., 2014. The Effects of Drought on Plant Communities in the Desert Rangelands of Tunisia, in: Gaur, R.K., Sharma, P. (Eds.), Approaches to Plant Stress and Their Management. Springer India, New Delhi, pp. 207-217. https://doi.org/10.1007/978-81-322$1620-911$

García del Toro, J.R., 1987. El hábitat eneolítico de Las Amoladeras (La Manga). Campañas 19811984. Memoria sucinta. Excavaciones y Prospecciones arqueológicas. Murcia, Servicio Regional de Patrimonio Historico. pp 65-92.

García-Pintado, J., Martínez-Mena, M., Barberá, G.G., Albaladejo, J., Castillo, V.M., 2007. Anthropogenic nutrient sources and loads from a Mediterranean catchment into a coastal lagoon: Mar Menor, Spain. Science of the Total Environment 373, 220-239.

Genin, D., 2006. Entre désertification et développement: la Jeffara tunisienne. IRD Editions.

Grimm, E.C., 1987. CONISS: a FORTRAN 77 program for stratigraphically constrained cluster analysis by the method of incremental sum of squares. Computers \& Geosciences 13, 13-35.

Heusser, L., Balsam, W.L., 1977. Pollen distribution in the northeast Pacific Ocean. Quaternary Research 7, 45-62.

Jaouadi, S., Lebreton, V., Bout-Roumazeilles, V., Siani, G., Lakhdar, R., Boussoffara, R., Dezileau, L., Kallel, N., Mannai-Tayech, B., Combourieu-Nebout, N., 2016. Environmental changes, climate and anthropogenic impact in south-east Tunisia during the last $8 \mathrm{kyr}$. Climate of the Past 12, 1339-1359. https://doi.org/10.5194/cp-12-1339-2016

Jiménez Castillo, P., 2013. Murcia. De la antigüiedad al islam (PhD Thesis). Universidad de Granada. 
Jiménez-Moreno, G., Anderson, R.S., 2012. Holocene vegetation and climate change recorded in alpine bog sediments from the Borreguiles de la Virgen, Sierra Nevada, southern Spain.

Quaternary Research 77, 44-53. https://doi.org/10.1016/j.yqres.2011.09.006

Jiménez-Moreno, G., Rodríguez-Ramírez, A., Pérez-Asensio, J.N., Carrión, J.S., López-Sáez, J.A., Villarías-Robles, J.J., Celestino-Pérez, S., Cerrillo-Cuenca, E., León, Á., Contreras, C., 2015. Impact of late-Holocene aridification trend, climate variability and geodynamic control on the environment from a coastal area in SW Spain. The Holocene 25, 607-617.

Lillo, M.J., 1981. Geomorfología del Mar Menor. Papeles del Departamento de Geografía 8, 9-48.

Manteca, J.-I., Ros-Sala, M., Ramallo-Asensio, S., Navarro-Hervás, F., Rodríguez-Estrella, T., CerezoAndreo, F., Ortiz-Menéndez, J.-E., de-Torres, T., Martínez-Andreu, M., 2017. Early metal pollution in southwestern Europe: the former littoral lagoon of El Almarjal (Cartagena mining district, SE Spain). A sedimentary archive more than 8000 years old. Environmental Science and Pollution Research 24, 10584-10603.

Manzano-Martínez, J., 2002. NOTAS SOBRE DEMOGRAFÍA ISLÁMICA EN MURCIA (SS. XIIXIII). Miscelánea Medieval Murciana XXV-XXVI, 117-181.

Martinez-Parras, M., Peinado, F., Alcaraz, J.M., 1992. Vegetation of Southeastern Spain. Schweizerbart Science Publishers, Stuttgart, Germany.

Martínez-Sánchez, C., San Nicolás-del Toro, 2003. El Neolítico en Murcia: continuidad y cambio durante el Calcolítico, in: Estudios de arqueología dedicados a la profesora Ana María Muñoz Amilibia, 2003, 155-174.Mederos, A., Ruiz Cabrero, L.A., 2004. El pecio fenicio del Bajo de la Campana (Murcia, España) y el comercio del marfil norteafricano.

Mittermeier, R.A., Turner, W.R., Larsen, F.W., Brooks, T.M., Gascon, C., 2011. Global Biodiversity Conservation: The Critical Role of Hotspots, in: Zachos, F.E., Habel, J.C. (Eds.), Biodiversity Hotspots: Distribution and Protection of Conservation Priority Areas. Springer, Berlin, Heidelberg, pp. 3-22. https://doi.org/10.1007/978-3-642-20992-5_1

Molina Molina, A., L., 2008. Cartagena y su término: de la Edad Media al siglo XIX, in: Estudios sobre desarrollo regional, 25-60.

Molina Molina, Á.L., Jiménez Alcázar, J.F., 1996. La frontera enquistada: el reino de Murcia a fines de la Edad Media. Meridies, III, 51-60

Navarro, T., Alados, C.L., Cabezudo, B., 2006. Changes in plant functional types in response to goat and sheep grazing in two semi-arid shrublands of SE Spain. Journal of Arid Environments 64, 298-322. https://doi.org/10.1016/j.jaridenv.2005.05.005

Noguera Celdrán, J.M., Antolinos Marín, J.A., 2009. Áreas productivas y zonas de servicio de la villa romana de Los Cipreses (Jumilla, Murcia). Archivo español de arqueología 82, 191-220.

Noguera-Celdrán, J.M., Marín, J.A.A., 2010. La villa de "Los Cipreses": un modelo para el análisis del poblamiento rural romano en la Llanura de Jumilla (Murcia), in: Poblamiento rural romano en el sureste de Hispania: 15 años después : Actas de las II Jornadas sobre Poblamiento rural romano en el sureste de Hispania, Museo Arqueológico de Murcia, 351-412.

Noguera-Celdràn, J.M., Antolinos-Marin, J.A., 2010. La villa de Los Cipreses: un modelo para el análisis del poblamiento rural romano en la Llanura de Jumilla (Murcia). Poblamiento rural romano en el sureste de Hispania: 15 años después 351.

Orejas, A., Ramallo, S., 2004. Carthago Noua: la ville et le territoire. Recherches récentes. Collection «ISTA» 922, 87-120.

Orejas, A., Sánchez-Palencia, F.J., 2002. Mines, Territorial Organization, and Social Structure in Roman Iberia: Carthago Noua and the Peninsular Northwest. American Journal of Archaeology 106, 581-599. https://doi.org/10.2307/4126218

Pantaléon-Cano, J., Yll, E.-I., Pérez-Obiol, R., Roure, J.M., 2003. Palynological evidence for vegetational history in semi-arid areas of the western Mediterranean (Almería, Spain). The Holocene 13, 109-119. https://doi.org/10.1191/0959683603hl598rp

Pérez-Picazo, M.T., Lemeunier, G., 1990. Agricultura y desarrollo regional en Murcia, 1750-1980. Áreas. Revista Internacional de Ciencias Sociales 12, 225-236.

Pérez-Ruzafa, A., Marcos, C., Pérez-Ruzafa, I.M., Ros, J., 1987. Evolución de las características ambientales y de los poblamientos del Mar Menor (Murcia, SE de España), in: Anales de Biología. Servicio de Publicaciones de la Universidad de Murcia, pp. 53-65. 
Pérez-Ruzafa, A., Marcos, C., Gilabert, J., 2005. The ecology of the Mar Menor coastal lagoon: a fast-changing ecosystem under human pressure. Coastal Lagoons: Ecosystem Processes and Modeling for Sustainable Use and Development. CRC Press, Boca Ratón, Florida 392-422.

Precioso-Arévalo, M.L., Rivera-Núñez, D., 2005. ESTUDIO ARQUEOBOTÁNICO DE LOS RESTOS DE" VITIS" EN LA REGIÓN DE MURCIA. Revista murciana de Antropología 12, 45-54.

Punt, W., 1976. The Northwest European Pollen Flora (NEPF) Vol I (1976), Vol II (1980), Vol III (1981), Vol IV (1984) Vol V (1988), Vol VI (1991), Vol VII (1996). Elsevier, Amsterdam.

Rameau, J.-C., Mansion, D., Dumé, G., 2008. Flore forestière française: région méditerranéenne. Forêt privée française.

Ramos-Román, M.J., Jiménez-Moreno, G., Anderson, R.S., García-Alix, A., Toney, J.L., JiménezEspejo, F.J., Carrión, J.S., 2016. Centennial-scale vegetation and North Atlantic Oscillation changes during the Late Holocene in the southern Iberia. Quaternary Science Reviews 143, 8495.

Ramos-Román, M.J., Jiménez-Moreno, G., Camuera, J., García-Alix, A., Anderson, R.S., JiménezEspejo, F.J., Carrión, J.S., 2018a. Holocene climate aridification trend and human impact interrupted by millennial-and centennial-scale climate fluctuations from a new sedimentary record from Padul (Sierra Nevada, southern Iberian Peninsula). Climate of the Past 14, 117 137.

Ramos-Román, M.J., Jiménez-Moreno, G., Camuera, J., García-Alix, A., Anderson, R.S., JiménezEspejo, F.J., Sachse, D., Toney, J.L., Carrión, J.S., Webster, C., 2018b. Millennial-scale cyclical environment and climate variability during the Holocene in the western Mediterranean region deduced from a new multi-proxy analysis from the Padul record (Sierra Nevada, Spain). Global and planetary change $168,35-53$.

Reille, M., 1992. Pollen et Spores d'Europe et d'Afric du Nort. Mar-seille: Laboratoire de Botanique historique et Palynologie, 520pp.

Reimer, P.J., Bard, E., Bayliss, A., Beck, J.W., Blackwell, P.G., Ramsey, C.B., Buck, C.E., Cheng, H., Edwards, R.L., Friedrich, M., 2013. IntCal13 and Marine13 radiocarbon age calibration curves 0-50,000 years cal BP. Radiocarbon 55, 1869-1887.

Sabatier, P., Dezileau, L., Briqueu, L., Colin, C., Siani, G., 2010. Clay minerals and geochemistry record from northwest Mediterranean coastal lagoon sequence: Implications for paleostorm reconstruction. Sedimentary Geology 228, 205-217. https://doi.org/10.1016/j.sedgeo.2010.04.012

Sánchez-Gómez, P., Guerra, J., Coy, E., Hernández, A., Fernández, S., Carrillo, A.F., 1998. Flora de Murcia. Claves de identificación e iconografía de plantas vasculares. Murcia: DM.

Stockmarr, J., 1971. Tablets with spores used in absolute pollen analysis. Pollen et spores 13,615621.

Sugita, S., 2007. Theory of quantitative reconstruction of vegetation I: pollen from large sites REVEALS regional vegetation composition. The Holocene 17, 229-241. https://doi.org/10.1177/0959683607075837

Thiébault, S., Moatti, J.-P., Ducrocq, V., Gaume, E., Dulac, F., Hamonou, E., Shin, Y.-J., Guiot, J., Cramer, W., Boulet, G., 2016. The Mediterranean region under climate change: a scientific update. IRD Editions, Marseille.

Torres-Fontes, J., 1976. Derrota cristiana en las playas de Campoamor en 1415. Murgetana XLV, 4956.

Turner, S.D., Brown, A.G., 2004. Vitis pollen dispersal in and from organic vineyards: I. Pollen trap and soil pollen data. Review of Palaeobotany and Palynology 129, 117-132.

Turon, J.-L., 1984. Le palynoplancton dans l'environnement actuel de l'Atlantique nord-oriental: évolution climatique et hydrologique depuis le dernier maximum glaciaire, Mémoires de l'Institut de géologie du bassin d'Aquitaine. Université de Bordeaux I.

Vilar, J.E., Egea Bruno, P.M., Fernandez Guttierez, J.C., 1990. La Mineria Murciana contemporanea. Universidad, Murcia, Espagne. 


\section{Appendix 1}

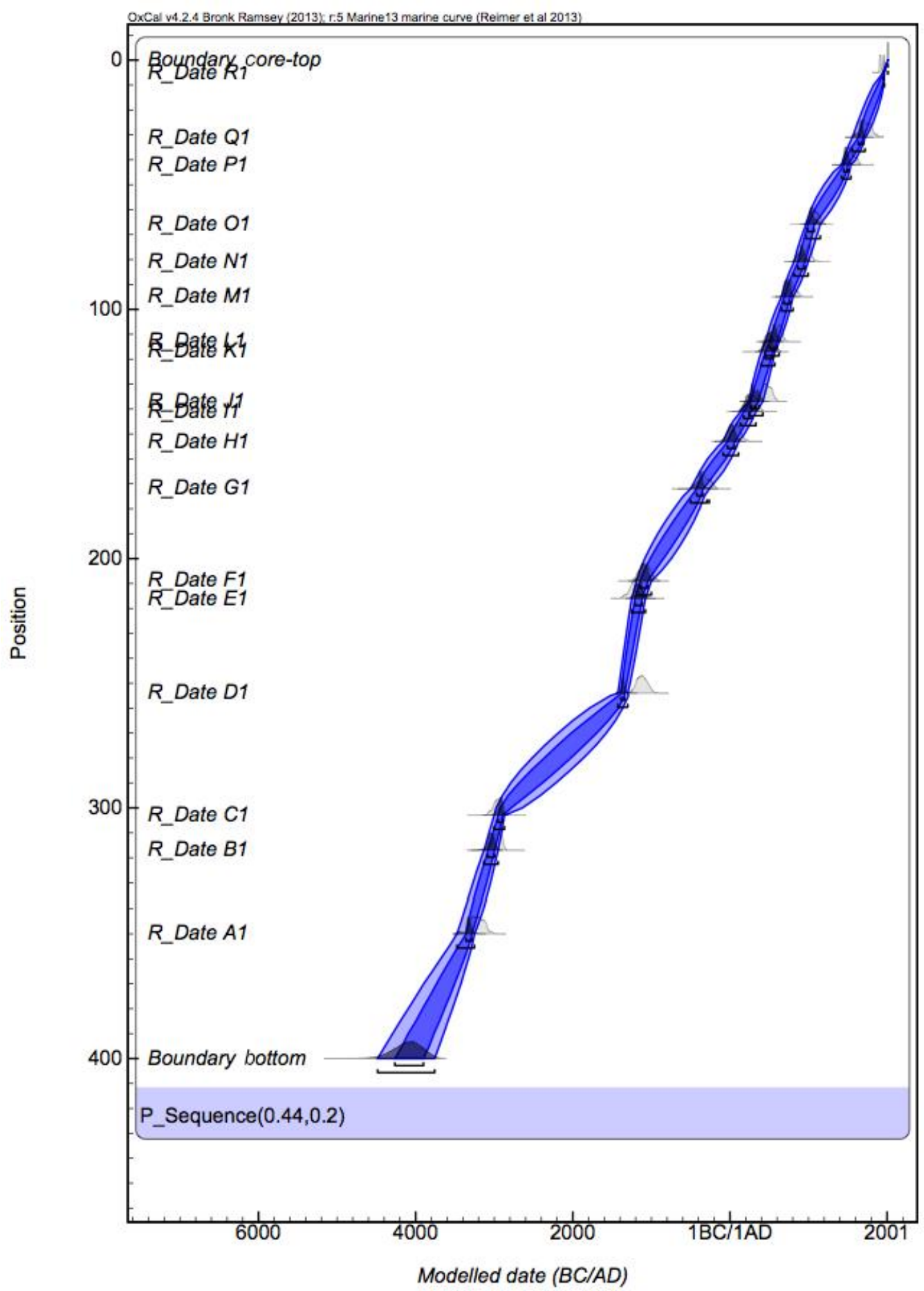

Figure A: Age model of MM2 core from Mar Menor lagoon (Dezileau et al. 2016) 


\begin{tabular}{|l|l|l|}
\hline Samples & depth $(\mathbf{c m})$ & $14 \mathrm{C}$ Age \\
\hline MM2A005 & 5 & $\mathbf{5 0 0} \pm \mathbf{3 0}$ \\
\hline MM2A031 & 31 & $1190 \pm 30$ \\
\hline MM2A-42 & 42 & $1395 \pm 30$ \\
\hline MM2A066 & 66 & $1950 \pm 30$ \\
\hline MM2A-81 & $\mathbf{3 1}$ & $\mathbf{2 0 2 5} \pm 30$ \\
\hline MM2A095 & 95 & $2230 \pm 30$ \\
\hline MM2A113 & 113 & $2395 \pm 31$ \\
\hline MM2A-117 & 117 & $2520 \pm 30$ \\
\hline MM2A137 & 137 & $2545 \pm 30$ \\
\hline MM2A-141 & 141 & $2710 \pm 30$ \\
\hline MM2A-153 & 153 & $2875 \pm 30$ \\
\hline MM2A172 & 172 & $3210 \pm 32$ \\
\hline MM2B-09 & 209 & $3835 \pm 30$ \\
\hline MM2B016 & 216 & $3930 \pm 30$ \\
\hline MM2B103 & 303 & $5290 \pm 34$ \\
\hline MM2B-117 & 317 & $5300 \pm 30$ \\
\hline MM2B150 & 350 & $5470 \pm 35$ \\
\hline
\end{tabular}

Table I : Radiocarbon dates along the MM2 core reported with a $1 \sigma$ uncertainty 